\title{
The Emergence of New Global Institutions: A Discursive Perspective*
}

\author{
Steve Maguire \\ Faculty of Management \\ McGill University \\ 1001 Sherbrooke West \\ Montreal, H3A 1 G5 \\ Canada \\ Email: steve.maguire@mcgill.ca \\ Tel: 1-514-398-2115 \\ Fax: 1-514-398-3876 \\ and \\ Cynthia Hardy \\ Department of Management \\ University of Melbourne \\ Parkville \\ Victoria, 3010 \\ Australia \\ Email: chardy@unimelb.edu.au \\ Tel: 61-3-8344-3719 \\ Fax: 61-3-8344-3731
}

\footnotetext{
* The authors gratefully acknowledge the financial support of the Social Sciences and Humanities Research Council of Canada, les Fonds pour la Formation des Chercheurs et l'Aide à la Recherche of Quebec, McGill University and the University of Melbourne in carrying out this research.
} 


\title{
The Emergence of New Global Institutions: A Discursive Perspective
}

\begin{abstract}
We examine how a new discourse shapes the emergence of new global regulatory institutions and, specifically, the roles played by actors and the texts they author during the institution building process, by investigating a case study of the Stockholm Convention on Persistent Organic Pollutants (POPs) and its relationship to the new environmental regulatory discourse of "precaution". We show that new discourses do not neatly supplant legacy discourses but, instead, are made to overlap and interact with them through the authorial agency of actors, as a result of which the meanings of both are changed. It is out of this discursive struggle that new institutions emerge.
\end{abstract}

KEYWORDS: institutions; discourse; multilateral environmental agreements; persistent organic pollutants; precautionary principle 


\section{Biographies}

Steve Maguire (steve.maguire@mcgill.ca) is Assistant Professor of Strategy and Organization in the Faculty of Management at McGill University. He received his Ph.D. from HEC-Montreal in 2000. His research focuses on institutional, technological and organizational change resulting when commercial, scientific and political struggles intersect around social or environmental issues. For example, his doctoral dissertation draws lessons from society's experience with the insecticide DDT and was awarded the Academy of Management's “Organization and Natural Environment (ONE)” Best Doctoral Dissertation Award in 2001. He has also studied the pharmaceutical industry, analysing the shifting relationship between pharmaceutical companies and people living with HIV/AIDS, and the impact this has had on the commercialization, availability and accessibility of HIV/AIDS treatments. In addition to Organization Studies, he has also published in the Academy of Management Journal, Strategic Organization, Global Governance, Health Care Management Review, Greener Management International, and Emergence.

Cynthia Hardy (chardy@unimelb.edu.au) has been Professor of Management at the University of Melbourne since 1998. Previously, she was a professor in the Faculty of Management at McGill University. Her research interests include power and politics in organizations, organizational discourse theory and critical discourse analysis, and she is particularly interested in how politics occur within larger discursive contexts. She recently published Discourse Analysis: Investigating Processes of Social Construction with Nelson Phillips, and co-edited a special issue of Organization Studies on organizational discourse as well as the Sage Handbook of Organizational Discourse. In total, she has published twelve books and edited volumes, including the Sage Handbook of Organization Studies, which won the George R. Terry Book Award at the 1997 Academy of Management. In addition to Organization Studies, her work has also appeared in other leading journals, including the Academy of Management Journal, Academy of Management Review, Journal of Management Studies, Human Relations, Organization Science, and California Management Review. 


\section{Introduction}

This paper examines how a new discourse influences the emergence of new global regulatory institutions. Specifically, it explores the emergence of the Stockholm Convention on Persistent Organic Pollutants (POPs), a new global regulatory institution that came into effect in 2004. This Convention incorporates an interpretation of the precautionary principle, which allows for the regulation of dangerous products based on their potential harm to human health and the environment. It immediately eliminates or restricts twelve chemicals classified as POPs (toxic chemicals such as PCBs and DDT) and also specifies a process for adding chemicals to the list of POPs in the future. It also lowers the burden on regulators of proving risk, enabling governments to take global action on chemicals despite scientific uncertainty regarding their harmful effects.

The precautionary principle can be traced back to the "foresight" principle in West German environmental law in the 1970’s and 1980’s (O’Riordan and Jordan 1995), and started to make its way into international law in the late 1980’s. It gained further momentum with the 1992 Rio Declaration on Environment and Development’s Principle 15:

In order to protect the environment, the precautionary approach shall be widely applied by States according to their capabilities. Where there are threats of serious or irreversible damage, lack of full scientific certainty shall not be used as a reason for postponing cost-effective measures to prevent environmental degradation (UNCED 1992).

In the environmental regulatory arena, precaution challenges the legacy discourse of science, which places the burden of proof on would-be regulators to demonstrate clear scientific evidence showing a product's harmful effects before implementing restrictions. In contrast, precaution enables regulatory action even where there is scientific uncertainty about a product's harmful effects (Wiener and Rogers 2002). The Stockholm Convention thus heralds 
major changes for the chemical industry, as well as those humans and ecosystems exposed to POPs. Given the economic and social importance of this new institution, it is useful to understand the “institutional structuring” process that gave rise to it (Whitley 2000).

We examine the role that the discourse of precaution played in the emergence of the Stockholm Convention. Our findings illustrate how, compared to legacy discourses, a new discourse creates new opportunities - or conditions of possibility - for actors, which in turn provide incentives for them to engage in institution building activities. New and legacy discourses also provide resources for these actors to use as they produce and distribute texts designed to influence the institution building process and its outcomes. Our study suggests different ways in which actors' texts engaged with these discourses and, particularly, how actors positioned new and legacy discourses in relation to each other in an ongoing struggle over meaning - in our case, the meaning of precaution. We illustrate how new discourses do not neatly supplant legacy discourses but, instead, are made to overlap and interact with them through the authorial agency of actors. It is out of this discursive struggle that new institutions emerge, momentarily stabilizing meanings and thus resulting in particular institutional outcomes.

Our study makes the following contributions. First, in studying the link between discourses and institutions, it provides insight into the dynamics of the emergence of a new global institution, indicating the importance of the discursive context within which new global regulatory institutions are built. Second, it highlights the role that actors play in institution building as authors of texts, and thus contributes to our understanding of the scope and limitations of agency. Third, it adds to our understanding of institutional change and institutional entrepreneurship by building on the emerging body of literature linking discourses and institutions, and providing a methodology that is sensitive to the dynamics of 
institutional change. Finally, it generates practical insights for actors involved in championing or shaping new institutions of this kind.

\section{Global Institution Building}

Our interest is in the field or policy domain (Laumann and Knoke 1989) of global environmental regulation. Such fields are constituted by sets of actors, including government bodies, business groups and NGOs, "who seek to influence a shared outcome (such as regulation) and pay attention to one another in the process” (McNichol and Bensedrine 2003: 220). They are arenas of power relations, where actors “compete over the definition of issues and the form of institutions that will guide organizational behavior” (Hoffman 1999: 352). Such transnational negotiations represent a space "where interactions take place and behavioral patterns get structured” in processes that are shaped by actors, and which, in certain circumstances, lead to the creation of new global regulatory institutions (Djelic and Quack 2003: 8).

Institutions set the "ground rules that establish the basis for production, exchange and distribution” (Davis and North 1971: 6). Operating at "a higher level of generalization than do markets and organizations: they delineate the rules of the game within which such ‘governance structures’ actually operate”, helping to “socially embed markets and organizations” (Menard 1995: 164). Our focus is on formal regulatory institutions (cf. Willman et al. 2003) in the environmental arena (cf. Hoffman 1999) that are transnational or global in scope (cf. McNichol and Bensedrine 2003). In addition to a specific set of legal texts, such regulatory institutions are comprised of systems of standards and penalties (Hoffman 1999), specialized organs for delegated decision making and review procedures (Sand 1990); secretariats (Bernauer 1995); and monitoring mechanisms (Mitchell 1994) which combine to influence behaviour (Hoffman and Ventresca 1999). The emergence of such global regulatory institutions is often characterized by struggles among a variety of state 
and non-state actors (e.g., Levy 1997) whose institution building activities merit more attention from researchers (Djelic and Bensedrine 2001).

Institutions are premised upon and supported by particular discourses (Selsky, Spicer and Teischer 2003; Phillips, Lawrence and Hardy 2004). Discursive activity is therefore one important means whereby actors engage in struggle over the emergence of new institutions: "studying talk is useful for understanding how actors negotiate new institutional orders - and deinstitutionalize old ones” (Clark and Jennings 1997: 462). Because institutions are "shaped and reshaped as a result of the complex dialectical interplay between pre-existing structural constraints and the combined collective efforts of corporate agents to engage in new modes of discursive practice”, studies of institution building activities should be sensitive to the use of discourses by interested actors (Reed 2004: 415).

Discourses are structured collections of meaningful texts - along with related the practices of producing, disseminating and consuming these texts - that "systematically form the object of which they speak" (Foucault 1979: 49) This is to say that objects - "particular parts of an ambiguous material world” - are made meaningful through discourses (Hardy and Phillips 1999: 3). Discourses create the ideas, categories, relationships, and theories through which actors understand the world and relate to one another (Grant and Hardy 2004). By constructing the meaning of these social categories, objects of knowledge, identities, social relationships, and conceptual frameworks, a discourse shapes "the strategies and rules by which we can speak about and act on a domain of objects ... in such a way that certain possibilities and outcomes are realized rather than others” (Reed 1998: 196). These possibilities and outcomes privilege certain actors at the expense of others and, by drawing on particular discourses, actors can create meanings that help to bring about their preferred outcomes (Deetz and Mumby 1990). 
Actors attempt to influence meaning through the production, dissemination and interpretation of texts, which include written texts (reports, memos, press releases, etc.) and spoken texts such as speeches, as well as meetings, public inquiries, etc. (Grant and Hardy 2005). As Chalaby (1996: 694) notes: "texts are weapons that agents in struggle use in their discursive strategies”, and so it is with institution building: “[actors] may produce texts that draw on discourses from other fields, or from society more generally, to produce new institutions or de-legitimate existing institutions” (Phillips et al. 2004: 1). A discourse thus not only constrains actors by structuring the social space within which they act, it also provides them with resources that they can mobilize through the production of texts (Hardy, Lawrence and Grant 2005) to create particular understandings and meanings that, in turn, shape institutions (Selsky et al. 2003).

In sum, discursive activity occurs during institution building as actors draw on different discourses in their texts to try to fix understandings, shape interpretations, and justify practices in ways that are commensurate with their interests. New discourses, in particular, provide opportunities to create new institutions and to change existing ones. As they do so, they both inherit "the cultural and political capital of older and long-established discourses" and, over time, "critique and challenge that very inheritance in their quest to change the institutional status quo in some shape or form” (Reed 2004: 415). Few empirical studies have, however, explored the relationship between new discourses, legacy discourses and global institution building. Accordingly, our research question is: how does a new discourse shape the emergence of new global institutions and what roles do actors and texts play in this process?

\section{The Case Study}

The Stockholm Convention on Persistent Organic Pollutants (POPs) is a global regulatory institution that came into effect in May 2004, incorporating an interpretation of the 
precautionary principle. It establishes new global rules for the production, use, import, export, release and disposal of dangerous chemicals classified as POPs. It comprises a legal text; monitoring, reporting and information exchange mechanisms; procedural rules for decisionmaking and for amending the Convention; and three new organizational units. The organizational units are: the Conference of the Parties (COP), which includes all signatory states; the POPs Review Committee (POPRC), comprised of "government-designated experts in chemical assessment or management” appointed by the COP "on the basis of equitable geographical distribution”; and a Secretariat.

POPs are "highly toxic" substances that "are persistent, lasting for years or even decades before degrading into less dangerous forms”, “evaporate and travel long distances through the air and through water" and "accumulate in fatty tissues” of humans and wildlife (UNEP 2002: 5). The Convention currently covers an initial list of twelve chemicals known as the "dirty dozen", banning or restricting ten intentionally produced chemicals, and obligating governments to reduce releases of two unintentional byproducts of industrial activity. The Convention also contains a provision for adding other chemicals to the list of POPs: any state that is party to the Convention can nominate additional POPs and, in so doing, trigger an evaluation by the POPRC, which then makes a recommendation to the COP.

The process that culminated in the Stockholm Convention began in February 1997, when the United Nations Environment Program's (UNEP) Governing Council set in motion an intergovernmental negotiating committee (INC) with a mandate, known as UNEP GC 19/13C, to develop an international legally binding instrument to address POPs. The legal text of the Convention was agreed over a series of five meetings of the INC that took place between July 1998 and December 2000. The Convention was officially adopted in May 2001. By August 2004, there were 151 signatory states. 
The meetings involved state and non-state actors. State actors were formal participants in the negotiating sessions where they proposed, debated and ultimately adopted the various articles and annexes of the legal text of the Convention. Proposals were made in written submissions and accompanied by formal interventions in the plenary sessions of the INC meetings. Other states reacted to these submissions and, if there was consensus, the proposal was adopted and incorporated into the draft. As observers, non-state actors such as NGOs and business associations could not make formal submissions, but they did intervene during plenary sessions with suggestions regarding the evolving legal text. These groups were also prominent "in the corridors" of each meeting where they set up information booths, distributed discussion documents and position papers, and lobbied state delegates.

Precaution was hotly debated in these meetings, reflecting a broader debate. Business commentators warn of "the perils of precaution", describing it as “inherently biased against change and therefore against innovation” (Miller and Conko 2001). Others claim it "poses a radical challenge to business as usual in a modern, capitalist, technological civilization” (Pollan 2001: 94). In contrast, many NGOs welcome it because of the reduced need to provide incontrovertible evidence of harm. States differ in their views: some - notably the EU - favour a greater emphasis on precaution in international environmental regulation; others, such as the US and the other JUSCANZ countries (Japan, Canada, Australia and New Zealand) are more likely to challenge such moves. Within this debate, precaution, as a relatively recent addition to environmental regulation, is commonly positioned in opposition to the traditional approach of science-based regulation referred to as "sound science” (Stirling 1999; Stirling and Gee 2002). 


\section{Methods}

\section{Site Selection}

We selected this case for its theoretical, practical and methodological significance. Theoretically, environmental issues are fruitful sites for studying processes of institutional emergence and change (Hoffman 1999) where discourses play an important role. Both precaution and sound science are discourses (Litfin 1994; 1995; Stirling 1999) constituted by a wide range of texts, including international legal instruments, national laws, academic journals from law, international relations and environmental studies, press articles, policy documents, speeches, etc. While the meaning of precaution continues to be debated, it nonetheless represents a new discourse that inherits, as well as challenges, the legacy scientific discourse. As a result, the research site was one where discourses and discursive activity by government, business and NGO stakeholders were expected to play an important role in global institution building.

The case study had practical significance because, if a new global regulatory institution did result, it would have significant implications for markets and organizations in the chemical industry, as well as for humans and the environment. The case also presented methodological opportunities since we could access a wide range of published texts that documented the emergence of the Convention, as well as the discursive activity of different stakeholders.

\section{Data Collection}

We collected texts from the formal negotiating process, including: the official draft versions of the legal text of the Convention published by UNEP after each meeting; papers from the meetings that contained actors' formal submissions proposing modifications to the evolving text; daily meeting reports produced by the Earth Negotiations Bulletin that contained summary details of all interventions by actors; texts produced by state, business, 
and NGO actors in their attempts to influence the Convention; and official UNEP documentation related to the POPs issue. We also collected a range of texts related to the precautionary principle and the Stockholm Convention, including scholarly articles from environmental studies, policy studies and law and press articles. Finally, we collected texts associated with other international legal instruments referencing the precautionary principle.

One of the authors attended three meetings of the INC, identified the actors that intervened, took notes on the nature of the interventions, and observed reactions to interventions. We conducted 40 interviews with state and non-state actors involved in the negotiations, which were taped and transcribed. Interviews were semi-structured, lasted between one and two hours, and involved asking interviewees to describe the POPs issue, the events leading up to the negotiations, and the negotiations themselves. Interviewees included government delegates actively involved in the negotiation and representing EU member states, the US, Canada, and Australia; representatives of health and environmental NGOs; industry representatives; and UNEP officials.

\section{Data Analysis}

We first constructed an "event history database” (Van de Ven and Poole 1990) by chronologically ordering descriptions of the process and juxtaposing the multiple accounts of events from different sources to ascertain convergence. This analysis captured "who did what, and when”. For each event, the relevant primary sources - the texts - were identified and chronologically ordered to comprise a “discursive-event history database” (Maguire 2004), capturing “who said what, and when”. In this way, we developed a narrative account (Eisenhardt and Bourgeois 1988) which chronicled the process that resulted in the Stockholm Convention, showing that precaution was a central and highly contentious issue throughout the negotiations. 
The remaining stages of analysis involved an iterative procedure that moved between theory, categories, and data (Miles and Huberman 1994; Yin 2003). We advanced broad themes developed from theory to frame the initial investigation of the data. We refined these themes by scrutinizing databases, interviews and texts for evidence to revise and elaborate our initial ideas into more precise categories. We then interrogated these categories by comparing and noting patterns, and by logging the evidence to support our interpretation (e.g., quotations, textual references, events, etc.), examples of which are presented in this paper. As additional evidence suggested modification or elimination, we continued until the original broad patterns were reduced to the conceptual categories presented here. Such systematic, interpretive methods are regularly used in empirical studies where phenomena are complex, context is important, relations among actors are multi-faceted and dynamic, and the research is based on social constructivist assumptions (Lee 1999; Phillips and Hardy 2002), as is the case here.

The second stage of analysis thus involved systematically comparing the two discourses of precaution and sound science using an established theoretical framework to advance three categories: object, concept, and subject position. Objects have an independent physical or material existence but, despite this, can only be understood with reference to the concepts applied to them (Hardy and Phillips 1999). Concepts are culturally and historically situated frames for understanding social reality - ideas, categories and theories through which we understand the world (Harré 1979). Subject positions are locations within the discourses from which certain delimited agents can act (Parker 1992): different subject positions have different rights to speak within a particular discourse (Potter and Wetherell 1987). Accordingly, we examined databases, interviews and texts to identify instances where precaution and sound science were discussed and explained. By exploring these instances in more detail, we identified the main material entity (object) addressed by each and found that, in both cases, it was a risk-generating products. We looked for the main ideas (concepts) used 
to make sense of these products, identifying scientific knowledge and risk, and we noted different patterns in the two discourses. We examined which categories of actors (subject positions) were named in the discussions of precaution and sound science and analyzed how they were described, again noting differences between the two discourses. Finally, we used another conceptual category - “conditions of possibility” that can be “drawn upon in the exercise of power” (Knights 1992: 530) - to distinguish the likely effects of the two discourses. To identify the conditions of possibility, we analyzed the two different configurations of objects, concepts and subject positions and identified how these constrained or enabled what could be said by whom and when, as well as how this affected power relations among the various categories of actors. This enabled us to identify the particular outcomes that the discourses were more likely to engender if actors used the meaning at their disposal, as we describe below.

In the third stage, we analyzed the texts produced by four key actors: the EU, the main state actor seeking to expand the scope of precaution (supported by Norway and Iceland); the International POPs Elimination Network (IPEN), a network of 350 NGOs and community groups from around the world and the main non-state actor seeking to expand the scope of precaution; the US, the main state actor seeking to limit the scope of precaution (supported by other JUSCANZ countries) and the International Council of Chemical Associations (ICCA), the main non-state actor seeking to limit the scope of precaution. Drawing on the work of Livesey (2002), we examined how actors’ texts drew on different discourses, specifically on the new and legacy discourses. We first identified instances where the texts made reference to precaution and whether it was related to mention of science. We then examined instances where both discourses were mentioned in more detail. We found clear patterns in how the two discourses were positioned in relation to each other: actors used their preferred discourse to challenge the opposing discourse; and they also tried to reconcile the two discourses. Finally, 
drawing on the concept of authoritative texts, we then identified instances where the texts made references to other texts (cf. Harley and Hardy 2004). We noted patterns in that different actors referred to different texts. When we explored how these various texts were referenced, we found that actors referenced particular texts strategically - either to open up or close down meaning, as discussed below.

The final stage of data analysis addressed institutional outcomes: whether and how precaution was incorporated into the final legal text of the Stockholm Convention. We first identified all the instances where the Convention text made reference to precaution, then we examined whether and how precaution was related to science. We found that the new discourse of precaution figures prominently in the legal text, as does the legacy discourse of science, but we also found a clear pattern in how the discourses were positioned: science was subordinated to precaution. We then examined the specific implications that this particular incorporation of precaution into the legal text of the Convention has for the global regulation of markets for chemical products, as our findings explain in more detail.

\section{Findings}

\section{Constructive Effects of Discourse}

Our first set of findings suggests that the two discourses create very different conditions of possibility through the interplay of objects, concepts, and subject positions (Table 1).

\section{- Table 1 near here -}

The focal objects of both discourses are risk-generating products, in this case, chemicals categorized as POPs, such as PCBs and DDT. Although the object is material, its meaning is variable: dangerous, safe, toxic, etc. (Maguire 2004). The discourse of sound science constructs the meaning of chemical products as safe until proven guilty, while the 
discourse of precaution constructs their meaning as potentially dangerous in the absence of further knowledge.

One key concept that influences the meaning of these objects is scientific knowledge. The discourse of sound science constructs scientific knowledge as something that experts can state with relative certainty about a given product. The discourse of precaution constructs scientific knowledge as uncertain and limited:

Yet, even most serious scientific works often prove to be misleading in the past concerning these substances. The POPs ... were in the past deemed to be so harmless, including by most brilliant scientists, that they were massively employed. ... This means that anywhere, governments must be in a position to act when science, because of a lack of scientific certainty, cannot assist them.... (EU 2000).

A second key concept is risk. The discourse of sound science stresses the importance of accurately assessing and demonstrating risk prior to government intervention. The discourse of precaution draws attention to potential risks of chemicals, and how even uncertain threats of harm should trigger societal deliberations about government intervention. Products thus become associated with different concepts in the two discourses - demonstrated risk or potential risk. In the case of the former, the absence of evidence is taken to mean that the product does not pose a risk; while the latter recognizes that products may pose an as yet unassessed risk. A third concept relates to ways of dealing with risk. The discourse of sound science is associated with the concept of risk management - actions aimed at lowering demonstrated risks below some acceptable level, and only after a rigorous and quantitative process of assessment. The discourse of precaution, although not incompatible with risk management (Maguire and Ellis 2003), is more strongly associated with the concept of risk avoidance. For example, IPEN (1998) recommended that "the goal of a global POPs 
convention must not be defined as the 'better management of risks associated with POPs'” but rather their "elimination”.

The two discourses also create different subject positions. The discourse of sound science privileges scientific experts, who are assumed to deliver hard facts to the policy process. Scientists still have discursive legitimacy in the discourse of precaution, but their position is diminished since they are seen as capable of producing only limited and uncertain knowledge. Their privileged positioned is also weakened by the greater role in decision making processes for the public and NGOs, who can legitimately voice concerns about chemical products on the basis of a lower threshold of evidence. Governments are also seen differently. According to sound science, governments are neutral consumers of scientific information that arbitrate on demonstrated risks and benefits, acting reactively after the facts have been established. Precaution views governments as arbiters of potential risks who act as defenders of human and environmental health. As such they are supposed to be attentive to weaker stakeholders and willing to take proactive, preemptive action. Finally, business has a voice but, under sound science, it is largely behind the scenes: they employ many of the scientists, fund much of the research, lobby governments, and are only infrequently called upon to defend their products. Precaution constructs business as one among a range of legitimate stakeholders, and requires them to defend more of their products, at an earlier stage, in order to respond to charges of potential harm.

These are things that I think would have been unlikely or very difficult to obtain twenty years ago. I think in many instances then the reaction of the industry was; "Make me. And then I'll sue you.” ... [Now they] have a certain responsibility to understand and anticipate a need (government delegate).

By shaping meaning through the interplay of different concepts, objects and subject positions, discourses also shape power relations among actors, constraining what can be said 
by whom. Sound science positions governments as reactive, marginalizes NGOs, and gives business more latitude to develop and continue to sell risky products until their harm is unequivocally established. The concept of demonstrated risk, given that scientific research is time-consuming, represents a resource for businesses in lengthening the process through which a specific risk is attached to a particular chemical product, which mainly benefits business.

Some people in government circles sometimes feel that when the industry starts thumping them for sound science, what they really mean is that they want you to research this for another five years so they don't have to do anything now (government delegate).

In this way, the discourse of sound science facilitates "non-decision making” (Bachrach and Baratz 1963) by governments and business. Precaution, on the other hand, empowers a wider range of actors, especially governments and NGOs, to play a role in the process whereby products are categorized as risky. By foregrounding the limitations of scientific knowledge and emphasizing the concept of potential risk, it is easier to trigger action at an earlier stage and directly challenge the validity of non-decision making and inaction.

Our findings indicate that the new and legacy discourses generate different conditions of possibility: the two configurations of objects, concepts and subject positions produce different meanings and power relations that, if acted upon, are likely to be associated with different outcomes. This means that governments, businesses, NGOs have strong incentives to engage in building institutions that will produce outcomes consistent with their interests, as well as potential resources to help them to do so. Conditions of possibility do not, however, fully determine outcomes, as the next section shows; actors must draw on them strategically by authoring texts if the possibilities are to be realized. 


\section{Discursive Strategies}

We noted the different ways the two discourses were positioned in relation to each other in actors' texts. First, texts drew on one discourse to challenge the other. For example, the EU emphasized the need for precaution because the scientific method, rather than removing uncertainty, actually produced it. "Scientific uncertainty results usually from five characteristics of the scientific method: the variable chosen, the measurements made, the samples drawn, the models used, and the causal relationship employed”, as well as “controversy on existing data or lack of some relevant data” and “uncertainty” related to “qualitative or quantitative elements of the analysis” (EC 2000: 13-14). Texts produced by IPEN highlighted how science produces uncertainty and leads to delays in action. They also claimed that traditional risk assessment and management practices are problematic because the risks associated with POPs are inherently unmanageable and that the only safe option is the precautionary goal of complete elimination:

Once a substance is listed as a POP, it is inappropriate to accept its continued generation and release into the environment. We reject the claim that emissions and releases of POPs can be effectively managed and controlled ... A POP has no acceptable emission limit, no acceptable daily intake, and no acceptable level in the environment. (IPEN 1998)

The US and the ICCA, in contrast, used science to challenge precaution.

[Industry] faces the prospect of having some chemicals, chemical groups, and entire technologies banned or strictly controlled as a result of government decisions that seem to apply the precautionary principle in a way that disregards important science ... (ICCA 2000a).

These actors argued that any new institution had to be guided by "the best scientific evidence to craft provisions to produce real reductions of the risk of POPs to health and the 
environment” (US 2000a) and to “promote actions that are feasible and practical” (ICCA 2000b).

Second, at the same time, actors tried to reconcile the two discourses in the texts they authored, and did so in different ways. The EU talked about science in ways that expanded the scope for invoking precaution. It argued that even "if scientific advice [concerning potential risk] is supported only by a minority fraction of the scientific community, due account should be taken of their views” (EC 2000: 16). Similarly, texts produced by IPEN did not reject science out of hand. Indeed, they often called for more scientific research in the form of "aggressive programs of toxicity testing” and emphasized that precaution was scientific insomuch as it "relies upon the weight of evidence approach” (IPEN 1998). But their construction of precaution was as "an overarching principle informing each step of the decision-making process” to which science and traditional risk assessment practices were subordinated (WWF, a member of IPEN 2000).

The US and ICCA also attempted to reconcile science and precaution, in this case by stressing how precaution should adhere to scientific tenets, such as traditional risk assessment practices.

Risk assessment is entirely consistent with the application of the precautionary principle. Indeed, the precautionary principle cannot be applied without a risk assessment (ICCA 2000a, emphasis in original)

Similarly, the US (2000b) argued that "precaution must be exercised as part of a sciencebased approach to regulation, and not as a substitute for such an approach”. These actors were prepared to "support precautionary language that is understood to be based in science" (US 2000b).

Third, actors' discursive strategies involved producing texts that invoked other authoritative texts that promoted particular meanings of precaution. The texts of EU and IPEN 
regularly referred to other legal texts that promoted the idea of precaution as an emerging principle of international law. For example, the EU's Communication from the Commission on the Precautionary Principle made explicit references to eight international instruments and asserted "this [precautionary] principle has ... become a full-fledged and general principle of international law" (EC 2000: 10). Similarly, the texts produced by IPEN drew attention to the texts of other multilateral environmental agreements and recommended that "POPs Treaty delegates should recognize the precautionary approach as an emerging principle of customary international law” (WWF, a member of IPEN 2000).

The US and ICCA were less likely to refer to legal texts that suggested that precaution was a legal principle and, in fact, preferred not to use the term principle at all.

And then you have somebody come in and they say "I like the word principle." It's like “No. No. You don’t really understand what’s at stake here. If you start calling this a Precautionary Principle now, we can’t sign. (JUSCANZ delegate) These actors preferred the term precautionary approach which had none of the far-ranging implications of a legal principle.

The texts of the US and ICCA frequently made reference to the Rio Declaration, which had a number of advantages for them. First, the Rio Declaration refers to a precautionary approach rather than precautionary principle. Second, it contains a weak formulation of precaution (Sandin et al 2002) in that it refers only to specific types of threats to the environment (those that are "serious or irreversible”) and justifies only "cost-effective” measures. (Texts authored by the EU and IPEN made reference to the Rio Declaration but, unlike those of the US and ICCA, also referred to legal texts of other global regulatory institutions such as the 2000 Cartagena Protocol on Biosafety which is a stronger formulation than the Rio Declaration. IPEN’s texts also referenced the 1998 Wingspread Statement, an even stronger NGO-authored formulation of precaution.) The third advantage of the Rio 
Declaration was that its (weaker) definition of precaution had been consensually agreed upon by the wider international community, enabling the US and ICCA to argue that there was no need to engage in further negotiations regarding the meaning of precaution.

[S]ome of the proposals that we have heard appear to be an effort to renegotiate Rio 15 . The U.S. strongly believes that this is not the forum to engage in that inherently political discussion (US 2000c).

These findings suggest that, despite the incentive that actors had for building institutions premised on one discourse rather than the other, they did not dismiss one discourse out of hand. Rather, actors engaged with both new and legacy discourses in more sophisticated ways, as summarized in Table 2. As a result, the struggle was not between actors promoting one discourse at the expense of the other; it was one of using resources provided by the discourses to promote and stabilize preferred meanings of precaution through strategies that included challenging and reconciling the discourses in different ways, as well as invoking different sets of authoritative texts. In this way, the EU and IPEN tried to expand the scope for precaution by exploiting the variability of meaning in the discursive context and citing a range of other texts. The US and ICCA tried to limit the scope for precaution and close down its meaning by referencing, in particular, the Rio Declaration.

—Table 2 near here -

\section{Institutional Outcomes}

The Stockholm Convention emerged from the attempts by actors to ensure it incorporated their preferred meaning of precaution, and the discursive strategies they used to achieve this end. While the text of the Stockholm Convention evokes both precaution and science, the meaning of precaution - and the outcomes that follow from this - result from how the two discourses appear and, in particular, their relationship to each other. 
Our analysis reveals that precaution figures prominently in the legal text of the Convention. First, the Preamble acknowledges that "precaution underlies the concerns of all the Parties and is embedded within this Convention." Second, the Objective is: "[m]indful of the precautionary approach as set forth in Principle 15 of the Rio Declaration on Environment and Development, the objective of this Convention is to protect human health and the environment from persistent organic pollutants.” This reference to precaution is particularly significant as the Objective is generally understood within international law to be an overarching article that guides interpretation of the substantive articles and provisions of a treaty (UN 1969: articles 31 and 32). Third, explicit reference to precaution is found in Annex C addressing “best available techniques.” Fourth, within the agreed process for adding other chemicals to the list of POPs, the technical threshold value of the persistence criteria for adding POPs to the Convention is set at a more precautionary level, as advocated by the EU and IPEN (although this is counterbalanced by the technical threshold value of the bioaccumulation criteria, which is set at a less precautionary level, as advocated by the US and ICCA). In addition, the agreed process for adding other chemicals to the list of POPs incorporates precaution by stating that "lack of full scientific certainty shall not prevent the proposal [to list a chemical as a POP] from proceeding” and by giving the Conference of the Parties (COP), the political body, final say over the POPs Review Committee (POPRC), the expert body, thus permitting chemicals that do not meet the technical criteria to be nonetheless categorized as POPs. In addition, it obligates the COP to take "due account” of "any scientific uncertainty” and to make decisions to list a chemical as a POP “in a precautionary manner”.

In contrast, no specific references to science or science-based decision making are made in the Preamble or the Objective. Science is mentioned in Annex C, but as only one of a list of thirteen factors whereas precaution underpins all thirteen (The Annex also draws 
attention to how scientific knowledge is subject to change, thus highlighting its uncertain and provisional status). Science figures most prominently in the provision for adding other chemicals to the list of POPs: the technical body (POPRC) first screens nominated chemicals using “science-based” criteria listed in Annex D along with scientific "evidence”, "monitoring data”, "measured levels”, etc. provided by the nominating party; then the POPRC conducts a more or less traditional risk assessment by preparing a "risk profile” that incorporates technical “information requirements” listed in Annex E. However, even here, the final decision on whether to add a nominated chemical to the list of POPs is taken by the political body - the COP, as noted above.

The Stockholm Convention thus incorporates the discourses of precaution and sound science in such a way that, while both are present, science has been subordinated to precaution. It is this incorporation of the new discourse into the legal text, along with its positioning vis à vis the legacy discourse, that shapes the outcomes of the new global institution. Prior to the Stockholm Convention, no global regulatory institution was available to address POPs (or chemicals with POPs-like features) about which there was scientific uncertainty. Such non-decision making, which advantaged business and disadvantaged NGOs as discussed in our first set of findings, is no longer the case. Not only have ten intentionally produced chemicals been banned or restricted (Table 3), but a transparent procedure for listing additional chemicals as POPs is now available to governments to seek proactive global regulation of chemicals with POPs-like features despite ongoing scientific uncertainty as to their precise risks, empowering NGOs and the public to lobby governments to take action on the basis of a lower burden of proof.

— Table 3 near here -

The significance of this procedure, which is science-based but which explicitly anticipates and accommodates scientific uncertainty in a way consistent with precaution, can 
be seen with, as of July 2005, the nomination of five additional chemicals with POPs-like features by various parties to the Convention (see Table 3). The regulatory fates of these chemicals are currently being deliberated “based on the need for precaution” (UNEP 2002: 11). As a result, the ongoing functioning of markets in these chemicals is now in question, and businesses that produce and use them have been called upon to defend them. Whether or not the chemicals are ultimately declared to be POPs and subsequently banned or restricted is not the point - decisions not to undertake precautionary actions are, after all, valid outcomes of precautionary deliberations (Maguire and Ellis 2005). Rather, it is the fact that they are being deliberated at all, and the speed with which actors have been able to put them onto the global regulatory decision making agenda, despite scientific uncertainty as to their risks, that underlines the importance of the new discourse of precaution in the Stockholm Convention.

Our findings indicate that, while incorporating a new discourse into the legal text of a global regulatory institution is important, actors must also pay attention to how it is positioned in relation to the legacy discourse. In other words, struggles around the building of new global regulatory institutions involve the ongoing negotiation of meaning - in this case, of precaution - which is momentarily stabilized in the new institution (although we can expect these negotiations to continue during subsequent interpretation and implementation of the legal text).

\section{Conclusions}

Our study provides an example of how a new discourse provided both incentives and resources for institution building. New discourses create different conditions of possibility compared to those produced by legacy discourses, potentially altering power relations among actors and motivating them to try to shape their institutional contexts through efforts at building institutions premised upon particular discourses to institutionalize particular power relations. New and legacy discourses also provide resources for these actors, who draw on 
them in different ways as they produce and distribute texts designed to influence the institution building process and its outcomes. Our study suggests that actors seeking to expand the impact of a new discourse do not simply promote it (for example, by challenging legacy discourses); they also produce texts that reconcile it with legacy discourses. Similarly, actors seeking to limit the impact of a new discourse do not simply defend legacy discourses or dismiss the new one but also attempt to reconcile them. Both sets of actors also draw on authoritative texts - in the case of the former, it is to open up the meaning of the new discourse and position it in a superior position to the legacy discourse; while the latter group tries to close down meaning and subordinate the new discourse to the legacy discourse. The different ways in which actors position new and legacy discourses in relation to each other represents an ongoing struggle over meaning that is stabilized in the new global institution, resulting in particular institutional outcomes. Thus new discourses do not neatly supplant the legacy discourses that they inherit but, instead, are made to overlap and interact with them by actors exercising authorial agency, as a result of which the meanings of both are changed. It is out of this discursive struggle that new institutions emerge.

Our study has limitations. As a single case study, its generalizability is inevitably limited. However, the focus on a single case study was necessary to investigate the process of emergence of a new global institution over time and in context to capture its complex dynamics. We focused on one particular new discourse, precaution, and tracked it in conjunction with its associated legacy discourse, sound science. Other discourses appeared in texts, but we felt it necessary to narrow our focus in order to conduct a more in-depth analysis of a manageable quantity of data. Finally, our analysis focused on publicly available, written texts and did not include private conversations. We accept that some negotiations occur behind closed doors but argue that the ensuing public texts are likely to provide traces of them. 
These limitations notwithstanding, our study makes a number of contributions. It highlights the importance of processes whereby meanings are negotiated in the emergence of new institutions. First, meaning is a weapon in the struggle: the actors in our study wanted different meanings of precaution to be incorporated into the Stockholm Convention and, as a result, developed strategies to deal with the increased variability of meaning that arises as a new discourse interacts with legacy discourses. Second, meaning is an outcome of the struggle - the particular meaning of precaution that was incorporated into the Stockholm Convention determines its effects on the global chemical industry. This Convention has far greater consequences for the chemical industry, not to mention human health and the environment, than previous regulatory institutions because the new discourse of precaution is incorporated in a way that positions it as superior to the legacy discourse. Since precaution has been positioned in opposition to other discourses in discussions of a range of other environmental issues, including innovation discourse in the case of genetically modified organisms (Miller and Conko 2001), and economic discourse in climate change (Levy and Kolk 2002), the focus on discourse would appear to be relevant to other institutional contexts.

At the same time, our study draws attention to strategies that may be unique to global institution building. In particular, it highlights the importance of strategies which reconcile new and legacy discourses: actors avoided an "either-or" framing with respect to the new and legacy discourse. This compromise made it easier to secure agreement among the many signatory states. Reconciliation strategies are of particular importance on the global stage because international law is "horizontal” (Brownlie 2003): international regulations are consensually agreed by sovereign states that voluntarily choose whether to participate. This is very different from domestic law, which is "vertical” (Brownlie 2003) in that a central state authority imposes regulations on citizens and organizations. Future research might investigate 
whether reconciliation strategies are relevant to the building of new regulatory institutions at municipal, regional, and national levels.

Finally, given the important role of texts in institution building processes (Phillips et al. 2004) our study is relevant to institution change more generally and, particularly, to institutional entrepreneurship (Maguire, Hardy and Lawrence 2004). Language has an important role to play in institutional change, as other writers are starting to realize. For example, Suddaby and Greenwood (2005) have noted the importance of rhetorical strategies in bringing about institutional change through the way in which they expose contradictory institutional logics. We complement such work by drawing attention to the discursive context in which language and rhetoric are embedded: institutional entrepreneurs need to be cognizant of and sensitive the discursive context in which they operate, especially with regard to the relationship between new and the legacy discourses. Within any discursive context, the conditions of possibility are just that - possibilities. They do not fully determine outcomes; only by drawing strategically on their discursive context, can actors author texts that influence whether and how possibilities are realized. Thus, for would-be institutional entrepreneurs and researchers alike, a discursive perspective is a promising approach to adopt. 


\section{References}

Bachrach, P. and M.S. Baratz

1963 'Decisions and nondecisions: An analytical framework'. American Political Science Review 57: 641-51.

Bernauer, T.

1995 'The effect of international environmental institutions: how we might learn more'. International Organization 49(2): 351-377.

Brownlie, I.

2003 Principles of public international law. Oxford: Oxford University Press.

Chalaby, J.K.

1996 'Beyond the prison-house of language: discourse as a sociological concept', British Journal of Sociology, 47(4): 684-698.

Clark, V. and P.D. Jennings

1997 'Talking about the Natural Environment'. American Behavioral Scientist 40(4): 454464.

Davis, L.E. and D.C. North

1971 Institutional change and American economic growth, Cambridge UK: Cambridge University Press.

Deetz, S. and D.K. Mumby

1990 'Power, discourse and the workplace: Reclaiming the critical tradition'. Communication Yearbook 13: 18-47.

Djelic, M-L. and S. Quack

2003 'Introduction: Governing globalization - bringing institutions back in' in Globalization and institutions: Redefining the rules of the economic game. M-L Djelic and S. Quack (eds), 1-14. Cheltenham, UK: Edward Elgar.

Djelic, M-L. and J. Bensedrine

2001 'Globalization and its Limits: The Making of an International Regulation' in The Multinational Firm: Organizing Across Institutional and National Divides. G. Morgan, P.H. Kristensen, and R. Whitley (eds.), 253-280. Oxford: Oxford University Press.

EC

2000 Communication from the Commission on the Precautionary Principle [COM(2000) 1 final: 2.2.2000]. Brussels: European Commission.

Eisenhardt, K.M. and L.J. Bourgeois

1988 'Politics of strategic decision making in high-velocity environments: Toward a midrange theory'. Academy of Management Journal, 31: 737-770. 
2000 The European Union and the Precautionary Principle: EU Presidency Speech. Pamphlet distributed at INC-5, Johannesburg, December 6, 2000.

Foucault, M.

1979 Discipline and punish: The birth of the prison. London: Penguin.

Grant, D. and C. Hardy

2004 'Struggles with organizational discourse’. Organization Studies 25(1): 5-14.

Hardy, C. and N. Phillips

1999 'No joking matter: Discursive struggle in the Canadian refugee system'. Organization Studies 20(1): 1-24.

Hardy, C., T. Lawrence and D. Grant

2005 'Discourse and collaboration: The role of conversations and collective identity'. Academy of Management Review, 30(1): 1-20.

Harley, B. and Hardy, C.

2004 'Firing blanks? An analysis of discursive struggle in HRM' Journal of Management Studies, 41(3): 377-400,

Harré, R.

1979 Social being: A theory for social psychology. Oxford: Basil Blackwell.

Hoffman, A.J.

1999 'Institutional evolution and change: Environmentalism and the U.S. chemical industry’. Academy of Management Journal 42: 351-371.

Hoffman, A.J. and M.J. Ventresca

1999 'The institutional framing of policy debates: Economics versus the environment' American Behavioral Scientist, 42(8): 1368-93.

ICCA

2000a ICCA Comments on the Application of the Precautionary Principle in Regulatory Decision-making. August 15, 2000. Pamphlet distributed at INC-5, Johannesburg.

ICCA

2000b UNEP Global POPs Treaty - INC5: ICCA Statement on Key Issues. August 31, 2000. Pamphlet distributed at INC-5, Johannesburg.

IPEN

1998 Background Statement and POPs Elimination Platform, Pamphlet distributed at INC1, Montreal, June 1998.

Jasanoff, S.

1997 'The political science of risk perception'. Reliability Engineering and System Safety 59: 91-99.

Knights, D. 
1992 'Changing spaces: The disruptive impact of a new epistemological location for the study of management'. Academy of Management Review 17(3): 514-36.

Laumann, E. O., and D. Knoke

1987 The organizational state: Social choice in national policy domains. Madison, Wisconsin: University of Wisconsin Press.

Lee, T.W.

1999 Using qualitative methods in organizational research. Thousand Oaks: Sage.

Levy, D.

1997 'Business and International Environmental Treaties: Ozone Depletion and Climate Change’. California Management Review 39(3): 54-71.

Levy, D. and A. Kolk

2002 'Strategic Responses to Global Climate Change: Conflicting Pressures on Multinationals in the Oil Industry'. Business and Politics 4(3): 275-300.

Litfin, K.

1994 Ozone discourse: Science and politics in global environmental cooperation. New York: Columbia University Press.

Litfin, K.

1995 'Precautionary Discourse and the Ozone Treaties'. Millenium 24(2): 251-277.

Livesey, S.M.

2002 'Global warming wars: Rhetorical and discourse analytic approaches to ExxonMobil's corporate public discourse'. Journal of Business Communication 39(1): 117-148.

Maguire, S.

2004 'The coevolution of technology and discourse: A study of substitution processes for the insecticide DDT'. Organization Studies 25(1):113-134.

Maguire S. and J. Ellis

2003 'The Precautionary Principle and Global Chemical Risk Management: Some Insights from POPs'. Greener Management International: The Journal of Corporate Environmental Strategy and Practice 41: 33-46.

Maguire, S. and J. Ellis

2005 'Redistributing the Burden of Scientific Uncertainty: Implications of the Precautionary Principle for State and Non-state Actors'. Global Governance, forthcoming.

Maguire, S., C. Hardy and T. Lawrence

2004 'Institutional entrepreneurship in emerging fields: HIV/AIDS treatment advocacy in Canada'. Academy of Management Journal 47(5): 1-23.

McNichol, J. and J. Bensedrine 
2003 'Multilateral rulemaking: transatlantic struggles around genetically modified food' in Globalization and institutions: Redefining the rules of the economic game. M-L Djelic and S. Quack (eds), 220-244. Cheltenham, UK: Edward Elgar.

Menard, C.

1995 'Markets as institutions versus organizations as markets? Disentangling some fundamental concepts' Journal of Economic Behavior and Organization 28: 161-182.

Miles, M.B. and Huberman, A.M.

1994 Qualitative data analysis: An expanded sourcebook, second edition. Thousand Oaks, CA: Sage.

Miller, H.I. and G. Conko

2001 'The perils of precaution'. Policy Review 107 (June):

[http://www.policyreview.org/jun01/miller.html , accessed 200501 21].

Mitchell, R.B.

1994 Intentional Oil Pollution at Sea: Environmental Policy and Treaty Compliance Cambridge, Mass.: MIT Press, 1994

O’Riordan, T. and A. Jordan

1995 'The precautionary principle in contemporary environmental politics'. Environmental Values 4: 191-212.

Parker, I.

1992 Discourse dynamics: Critical analysis for social and individual psychology. London: Routledge.

Phillips, N. and C. Hardy

2002 Understanding discourse analysis. Thousand Oaks, CA: Sage.

Phillips, N., T. Lawrence and C. Hardy

2004 'Discourse and institutions'. Academy of Management Review 29(4): 1-18.

Pollan, M.

2001 'Precautionary principle’. New York Times Magazine [December 9, 2001]: 92-93.

Potter, J. and M. Wetherell

1987 Discourse and social psychology: Beyond attitudes and behavior. London: Sage.

Reed, M.

1998 'Organizational analysis as discourse analysis: A critique' in Discourse and organization. T.K.D. Grant and C. Oswick (eds), 193-213. London: Sage.

Reed, M.

2004 'Getting real about organizational discourse' in Handbook of organizational discourse. D. Grant, C. Hardy, C. Oswick, and L. Putnam (eds), 413-420. London: Sage.

Sand, P.H. 
1990 'Innovations in International Environmental Governance’. Environment 32: 16-44.

Sandin, P., M. Peterson, S.O. Hansson, C. Ruden and A. Juthe

2002 'Five charges against the precautionary principle'. Journal of Risk Research 5(4): 287299.

Selsky, J.W., A. Spicer and J. Teicher

2003 ' 'Totally un-Australian!': Discursive and institutional interplay in the Melbourne port dispute of 1997-98'. Journal of Management Studies 40(7): 1729-1760.

Stirling, A.

1999 On Science and Precaution in the Management of Technological Risk. Brussels: European Commission Joint Research Centre.

Stirling, A. and D. Gee

2002 'Science, Precaution and Practice’. Public Health Reports 117: 521-533.

Suddaby, R. and R. Greenwood

2005 'Rhetorical Strategies of Legitimacy’, Administrative Science Quarterly 50(1): 35-68.

UN

1969 "Vienna Convention on the Law of Treaties", United Nations Treaty Series, 1155: 331.

UNCED [United Nations Commission on Environment and Development]

1992 Rio declaration on environment and development. New York: United Nations.

UNEP

2002 Ridding the World of POPS: A Guide to the Stockholm Convention on Persistent Organization Pollutants. UNEP (United Nations Environment Programme:

Switzerland.

US

2000a US Objectives for a Global Treaty on Persistent Organic Pollutants. November, 29 2000. Fact sheet released by the Bureau of Oceans and International Environmental

US and Scientific Affairs, US Department of State.

2000b United States Position on Precaution. December 4, 2000, press release.

US

2000c Opening Statement of the United States, by Brooks Yeager, Head of the U.S. Delegation to Persistent Organic Pollutants Negotiations INC-5, Johannesburg, South Africa, December 4, 2000.

Van de Ven, A.H. and M.S. Poole.

1990 'Methods for Studying Innovation Development in the Minnesota Innovation Research Program’. Organization Science 1/3: 313-334.

Whitley, R. 
2000 'The institutional structuring of innovation strategies: Business systems, firm types, and patterns of technical change in different market economies'. Organization Studies 21(5): 855-886.

Wiener J.B. and M.D. Rogers

2002 'Comparing precaution in the United States and Europe'. Journal of Risk Research 5(4): 317-349.

Willman, P., D. Coen, D. Currie and M. Siner

2003 'The evolution of regulatory relationships: Regulatory institutions and firm behaviour in privatized industries'. Industrial and Corporate Change 12(1): 69-89.

WWF

2000 UNEP Global POPs Treaty (INC5/Johannesburg), Incorporating Precautionary Measure” August, 2000. Pamphlet distributed at INC-5, Johannesburg.

Yin, R.K.

2003 Case study research: Design and methods, third edition. Thousand Oaks, CA: Sage Publications. 
Table 1: Comparing the Discourses

\begin{tabular}{|c|c|c|}
\hline $\begin{array}{l}\text { Element of } \\
\text { Discourse }\end{array}$ & Discourse of Sound Science & Discourse of Precaution \\
\hline Object & $\begin{array}{l}\text { Risk-generating products, such as chemicals } \\
\text { (e.g., PCBs, DDT, etc.) }\end{array}$ & $\begin{array}{l}\text { Risk-generating products, such as chemicals } \\
\text { (e.g., PCBs, DDT, etc.) }\end{array}$ \\
\hline Key concepts & $\begin{array}{l}\text { Sound scientific knowledge } \\
\text { Demonstrated risk } \\
\text { Risk assessment, analysis and management }\end{array}$ & $\begin{array}{l}\text { Uncertain, limited scientific knowledge } \\
\text { Potential risk } \\
\text { Risk avoidance }\end{array}$ \\
\hline $\begin{array}{l}\text { Key subject } \\
\text { positions }\end{array}$ & $\begin{array}{l}\text { Scientific experts supply hard "black- } \\
\text { boxed" facts to the policy process. } \\
\text { Governments are arbiters of demonstrated } \\
\text { risks and benefits; they trigger policy } \\
\text { conversations and regulate accordingly. } \\
\text { Non-government organizations can } \\
\text { legitimately voice concerns about } \\
\text { demonstrated risks. } \\
\text { Business organizations respond to concerns } \\
\text { about demonstrated risks. }\end{array}$ & $\begin{array}{l}\text { Scientific experts supply soft, contested } \\
\text { claims to the policy process. } \\
\text { Governments are arbiters of potential risks } \\
\text { and benefits; they trigger policy } \\
\text { conversations and regulate accordingly. } \\
\text { Non-government organizations can } \\
\text { legitimately voice concerns about potential } \\
\text { risks. } \\
\text { Business organizations respond to concerns } \\
\text { about potential risks. }\end{array}$ \\
\hline $\begin{array}{l}\text { Conditions of } \\
\text { possibility }\end{array}$ & $\begin{array}{l}\text { "Scientific uncertainty justifies inaction" is } \\
\text { a valid discursive construction for } \\
\text { governments. } \\
\text { "This product is associated with that risk" is } \\
\text { a valid discursive construction for scientific } \\
\text { experts, and is more likely to come later } \\
\text { rather than earlier. }\end{array}$ & $\begin{array}{l}\text { "Scientific uncertainty justifies inaction" is } \\
\text { not a valid discursive construction for } \\
\text { governments, or for those seeking to } \\
\text { influence them. It is explicitly ruled out by } \\
\text { the precautionary principle (see Principle } 15 \\
\text { of Rio Declaration). } \\
\text { "This product is associated with that risk" is } \\
\text { a valid discursive construction for other } \\
\text { actors in addition to scientific experts, and } \\
\text { is more likely to come earlier rather than } \\
\text { later. }\end{array}$ \\
\hline
\end{tabular}




\section{Table 2: Discursive Strategies}

\begin{tabular}{|c|c|c|c|}
\hline \multicolumn{2}{|c|}{ Actors seeking to expand scope of precaution } & \multicolumn{2}{|c|}{ Actors seeking to limit scope of precaution } \\
\hline EU Texts & IPEN Texts & US Texts & ICCA Texts \\
\hline $\begin{array}{l}\text { Challenge discourse of sound science } \\
\text { by claiming sound science can } \\
\text { produce uncertainty; lead to delays in } \\
\text { action }\end{array}$ & $\begin{array}{l}\text { Challenge discourse of sound science } \\
\text { by claiming sound science can } \\
\text { produce uncertainty; lead to delays in } \\
\text { action; and is inappropriate for } \\
\text { addressing POPs because they pose } \\
\text { unmanageable risks }\end{array}$ & $\begin{array}{l}\text { Challenge discourse of precaution by } \\
\text { claiming precaution can be } \\
\text { impractical }\end{array}$ & $\begin{array}{l}\text { Challenge discourse of precaution by } \\
\text { claiming precaution can be } \\
\text { impractical; and is inappropriate for } \\
\text { addressing POPs because it can lead } \\
\text { to an unmanageable institutional } \\
\text { regime }\end{array}$ \\
\hline $\begin{array}{l}\text { Reconcile the discourses by: } \\
\text { constructing precaution as scientific; } \\
\text { subordinating key features of sound } \\
\text { science to precaution }\end{array}$ & $\begin{array}{l}\text { Reconcile the discourses by: } \\
\text { constructing precaution as scientific; } \\
\text { subordinating key features of sound } \\
\text { science to precaution }\end{array}$ & $\begin{array}{l}\text { Reconcile the discourses by: } \\
\text { constructing sound science as } \\
\text { precautionary; subordinating key } \\
\text { features of precaution to sound } \\
\text { science }\end{array}$ & $\begin{array}{l}\text { Reconcile the discourses by: } \\
\text { constructing sound science as } \\
\text { precautionary; subordinating key } \\
\text { features of precaution to sound } \\
\text { science }\end{array}$ \\
\hline $\begin{array}{l}\text { Invoke } \\
\text { - Rio Principle 15: to legitimate } \\
\text { precaution } \\
\text { other international legal texts } \\
\text { (e.g. Cartagena Protocol): to } \\
\text { emphasize "precautionary } \\
\text { principle” and claim status as } \\
\text { legal principle; to illustrate that } \\
\text { precaution can be operationalized } \\
\text { in substantive provisions }\end{array}$ & $\begin{array}{l}\text { Invoke } \\
\text { - } \quad \text { Rio Principle 15: to legitimate } \\
\text { precaution } \\
\text { - } \text { other international legal texts } \\
\text { (e.g. Cartagena Protocol): to } \\
\text { emphasize "precautionary } \\
\text { principle” and claim status as } \\
\text { legal principle; to illustrate that } \\
\text { precaution can be operationalized } \\
\text { in substantive provisions } \\
\text { - Wingspread Statement: to } \\
\text { highlight stronger formulation }\end{array}$ & $\begin{array}{l}\text { Invoke } \\
\text { - Rio Principle } 15 \text { to emphasize } \\
\text { "precautionary approach” and } \\
\text { challenge status as a legal } \\
\text { principle: to promote weak } \\
\text { formulation; to secure discursive } \\
\text { closure around its weak } \\
\text { formulation through a } \\
\text { consensually agreed document; } \\
\text { to argue for scientific (cost- } \\
\text { effective) approach to precaution }\end{array}$ & $\begin{array}{l}\text { Invoke } \\
\text { - Rio Principle 15: to emphasize } \\
\text { “precautionary approach” and } \\
\text { challenge status as a legal } \\
\text { principle; to promote weak } \\
\text { formulation; to secure discursive } \\
\text { closure around its weak } \\
\text { formulation through a } \\
\text { consensually agreed document; } \\
\text { to argue for a scientific (cost- } \\
\text { effective) approach to precaution }\end{array}$ \\
\hline
\end{tabular}


Table 3: Institutional Outcomes

\begin{tabular}{|c|c|c|}
\hline & $\begin{array}{c}<\text { May } 2004 \\
\text { (pre-Stockholm Convention) }\end{array}$ & $\begin{array}{c}\text { > May } 2004 \\
\text { (with Stockholm Convention) }\end{array}$ \\
\hline $\begin{array}{l}\text { Global institutional } \\
\text { context }\end{array}$ & $\begin{array}{l}\text { No global regulatory institution addresses } \\
\text { POPs. }\end{array}$ & $\begin{array}{l}\text { Stockholm Convention on POPs bans nine } \\
\text { intentionally produced chemicals (aldrin, } \\
\text { chlordane, dieldrin, endrin, HCB, } \\
\text { heptachlor, hexachlorobenzene, mirex, } \\
\text { toxaphene), restricts one other (DDT), and } \\
\text { obligates governments to reduce releases of } \\
2 \text { unintentionally produced by-products } \\
\text { (dioxins, furans). } \\
\text { Stockholm Convention on POPs specifies a } \\
\text { science-based procedure for adding } \\
\text { chemicals to the list of POPs, but one which } \\
\text { explicitly accommodates scientific } \\
\text { uncertainty, subordinates the technical body } \\
\text { (POPRC) to the political body (COP), and } \\
\text { obligates the COP to make listing decisions } \\
\text { "in a precautionary manner”. }\end{array}$ \\
\hline $\begin{array}{l}\text { Implications for } \\
\text { markets }\end{array}$ & $\begin{array}{l}\text { Domestic markets in POPs exist in some } \\
\text { states but not in others due to heterogeneous } \\
\text { regulations. } \\
\text { International markets in POPs are } \\
\text { unrestricted, except through heterogeneous } \\
\text { domestic controls on import and export. } \\
\text { Markets in products with POPs-like features } \\
\text { but about which there is scientific } \\
\text { uncertainty as to their risks continue to } \\
\text { function while scientists characterize, assess } \\
\text { and attempt to demonstrate their risks. }\end{array}$ & $\begin{array}{l}\text { Domestic markets in banned POPs do not } \\
\text { exist due to harmonized regulations among } \\
\text { states which are Parties to the Convention.* } \\
\text { Domestic markets in restricted POPs are } \\
\text { highly constrained and in a harmonized } \\
\text { manner among Party states. } \\
\text { International markets in banned POPs do } \\
\text { not exist between states which are Parties to } \\
\text { the Convention.* International markets in } \\
\text { restricted POPs are highly constrained and } \\
\text { in a harmonized manner among Party states. } \\
\text { Markets in products with POPs-like features } \\
\text { are more likely to be deliberated and } \\
\text { regulated earlier because of the lower } \\
\text { threshold of evidence of risk required. For } \\
\text { example, as of July 2005, five chemicals - } \\
\text { pentabromodiphenyl ether (by Norway), } \\
\text { chlordecone (EU), hexabromobiphenyl } \\
\text { ether (EU), lindane (Mexico), } \\
\text { perfluorooctane sulfonate (Sweden) - had } \\
\text { already been nominated as potential } \\
\text { additions to the list of POPs. }\end{array}$ \\
\hline
\end{tabular}

* With some exceptions; the Stockholm Convention on POPs allows states to register exemptions. 


\section{University Library}

\section{- M M N E R VA A gateway to Melbourne's research publications}

Minerva Access is the Institutional Repository of The University of Melbourne

Author/s:

Maguire, S; Hardy, C

Title:

The emergence of new global institutions: A discursive perspective

Date:

2006-01-01

Citation:

Maguire, S. \& Hardy, C. (2006). The emergence of new global institutions: A discursive perspective. ORGANIZATION STUDIES, 27 (1), pp.7-29. https:// doi.org/10.1177/0170840606061807.

Persistent Link:

http://hdl.handle.net/11343/116074 